\title{
SISTEMAS FECHADOS EM VIAS DE MIDIATIZAÇÃO
}

\section{Bruno Garcia Vinhola ${ }^{1}$}

\section{Resumo}

O presente texto tem por objetivo refletir sobre como a nova ambiência da sociedade em vias de midiatização tem afetado até mesmo as instituições consideradas mais fechadas. Elege-se como objeto o Exército Brasileiro, ao analisar como suas práticas de sociabilidade têm respondido à problemática da midiatização. Ao trabalhar a transição da sociedade dos meios para a sociedade em vias de midiatização, examinam-se as mudanças nas interações entre campos e atores sociais, procurando encontrar em nosso objeto sinais dos efeitos que a midiatização pode causar em instituições resistentes por essência.

Palavras-chave: Midiatização, campos sociais, interações, instituição total, Exército Brasileiro.

\begin{abstract}
The aim of this paper is to discuss how the new ambience of society on the verge of mediatization has affected even conservative institutions. We choose the Brazilian Army as our study object and we analyze how its practices of sociability have reacted to the mediatization. As we study the transition between the media society to the society on the verge of mediatization, we examine the changes in interactions between fields and social actors, trying to find in our object signs of the effects which mediatization can cause in tough institutions.
\end{abstract}

Keywords: Mediatization, social fields, interactions, total institutions, Brazilian Army.

\section{Introdução}

Em seu estudo sobre manicômios, presídios e conventos, Goffman (2001) indicou o termo "instituição total" para traduzir aquelas instituições que, no mundo ocidental até então conhecido, se apresentavam como mais fechadas do que as demais, devido aos métodos em que as interações se desenvolviam dentro de tais sistemas. Em resumo, dentre as características básicas, podemos ressaltar que se tratavam de locais de resistência e trabalho que englobavam indivíduos convivendo nas mesmas condições, separados da sociedade comum e dentro de um regime fechado. A administração desse contexto é baseada na formalidade, na rigidez e na hierarquia.

Tomamos de empréstimo o conceito de Goffman para nos aproximarmos do nosso objeto de análise, o Exército Brasileiro. Afinal, hierarquia descendente, disciplina rígida, clausura e formalismo já nos garantem uma rápida conexão com o que conhecemos da realidade da caserna. Mas Goffman (2001, p.16) ainda enumera os cinco tipos de instituição total, deixando um espaço reservado para o Exército $^{2}$ no grupamento das “instituições estabelecidas

\footnotetext{
1 Mestrando no Programa de Pós-Graduação em Ciências da Comunicação da Unisinos. E-mail: brunovinhola@hotmail.com.

${ }^{2}$ Goffman refere-se a quartéis em geral, equiparando-os a navios, escolas internas, campos de trabalho, entre outras instituições.
} 
com a intenção de realizar de modo mais adequado alguma tarefa de trabalho, e que se justificam apenas através de tais fundamentos instrumentais".

O resgate do estudo de Goffman serve como apoio para esclarecermos e justificarmos o objeto. Com o conceito de instituição total, aqui aproximado do Exército Brasileiro, queremos simbolizar aqueles sistemas que são reativos por natureza, extremamente fechados e resistentes a adaptações. A partir do exame da transição da sociedade dos meios para a sociedade em vias de midiatização e visitando as construções teóricas que envolvem a temática da midiatização, pretende-se analisar como o Exército Brasileiro, um representante das instituições totais, responde à problemática da midiatização. Partindo da proposta de que a midiatização produz afetações em todas as práticas de sociabilidade, queremos analisar até que ponto os sistemas mais fechados resistem aos desvios provocados por essa nova ambiência. Adaptar-se ou não? Transformar o fechado em aberto? Fragilidade dos discursos tradicionais? Perguntas como essas tencionam qualquer instituição que participa dessa transição para a sociedade midiatizada. Para as instituiçõos totais, o amadurecimento de tais práticas se revela ainda mais complexo.

\section{Ruptura ou continuidade?}

A pergunta acima instiga os que se propõem a discutir as lógicas de transição da sociedade dos meios para a sociedade em vias de midiatização. Enquanto alguns autores e pensadores encaram as mudanças provocadas na sociedade como rupturas aos padrões de interação até então estabelecidos, outros enxergam como uma questão de continuidade, em que o histórico e o contextual devem ser levados em consideração. Gomes (2014), por exemplo, define essa nova ambiência como um estágio na evolução, um salto qualitativo da sociedade. Por essa definição do autor, podemos responder à pergunta? Ou encontramos, ao mesmo tempo, sinais de ruptura e de continuidade?

Neste texto estaremos alinhados com a perspectiva da continuidade para, a partir dela, introduzirmos outra importante questão que permeia a temática da midiatização: a ideia de que é um conceito não fechado. Algo em desenvolvimento, não naturalizado. Autores como Fausto Neto e Braga explicam que as teorias clássicas de fundo, ainda que nos auxiliem, são insuficientes para o entendimento dos fenômenos da sociedade midiatizada. A midiatização não é mais ou menos do que as demais teorias. Trata-se apenas de uma realidade diferente. Um diferente com construções em seu entorno, em continuidade e atravessado pelo complexo.

A perspectiva da continuidade e a ideia de um conceito não fechado nos servem de base para adentrarmos no entendimento da transição da sociedade dos meios para a sociedade em vias de midiatização. O contínuo significa a midiatização como um fenômeno incompleto por 
essência, como veremos adiante. E no incompleto buscamos o significado do uso da expressão "em vias de midiatização", que marca a característica de um conceito ainda não acabado.

Começamos pela sociedade dos meios ou dos mídias. Como sua característica básica, a centralidade dos meios de comunicação. A sociedade estava estruturada nos meios, que bem marcados por ela enquadravam o mundo e organizavam a vida social conforme suas dinâmicas. A partir das agendas, das formações de opinião, garantiam as estruturas. Em uma comunicação baseada na linearidade emissor-receptor, em um modelo "um para todos", a mediação estava sob a responsabilidade dos meios.

Quando falamos na centralidade dos meios, nos referimos à centralidade de sua técnica. Inatingível aos demais campos sociais no período da sociedade dos meios, a técnica era a garantia da autonomia do campo dos media. A sociedade valorizava a instrumentalidade dos meios que, com sua técnica, constituíam a própria sociedade.

Rodrigues (2000) tem sua obra marcada pela defesa da autonomização do campo dos media. Segundo o autor, fronteiras constituem áreas de interface entre os campos sociais e a autonomização do campo dos media faz com que ele se torne o grande articulador das relações. Por sua natureza tecnossimbólica, o campo dos media tem a capacidade para superintender, falando de tudo, de uma maneira acessível a todos. Anteriormente, cada campo social procurava impor suas lógicas para a sociedade a partir do saber de seus especialistas. A sociedade dos meios quebra a limitação da mediação dos domínios da experiência, pois faz surgir tensões entre os campos sociais em consequência da gestão das relações por parte do campo dos media. Todos os campos se valem do campo midiático para expor seu saber, e isso expande cada vez mais o domínio dos meios. Nas fronteiras entre os campos, apenas o campo dos media possui legitimidade. A tematização pública é responsabilidade do campo midiático e os discursos especializados estão submissos à centralidade da sua técnica.

\footnotetext{
São doravante essas novas questões que irão mobilizar o debate público que o campo dos media se encarrega de promover e publicitar. Fazendo intervir, ao mesmo tempo, problemas de natureza científica, política, econômica, religiosa, médica, essas novas questões mostram os limites da legitimidade de cada um dos campos sociais instituídos ao longo da modernidade para a formulação e a imposição de valores consensuais e de regras suscetíveis de regular os comportamentos adequados. É no campo dos media que essas novas questões se irão reflectir e problematizar (RODRIGUES, 2009, p. 201).
}

A autonomização do campo dos media e a consequente dependência dos demais campos sociais fez com que a pergunta frequente na sociedade dos meios fosse: o que os meios fazem com as pessoas? Afinal, eles acabavam controlando o tecido social. E hoje, essa pergunta 
carrega a mesma importância? Com essa reflexão começamos a pensar na sociedade em vias de midiatização e no que caracteriza o processo dessa transição.

A necessidade de legitimação dos campos sociais é crescente até hoje. Se na sociedade dos meios, sujeitos e instituições se valiam do campo midiático para tematizar no espaço público o que estava fragmentado, na transição para a sociedade em vias de midiatização, sujeitos e instituições passaram a perceber que não dependiam dos meios. O que precisavam, então? Apenas dominar sua técnica.

O acelerado desenvolvimento tecnológico e digital, aliado às consequentes apropriações sociais das tecnologias - que desviam o foco das invenções fazendo surgir novos usos até então imprevistos - possibilitou a conversão de diversas tecnologias em meios de comunicação. Essa reconfiguração das invenções a partir das práticas sociais criou condições para que todos os campos sociais se apropriassem das tecnologias. Ou seja, na sociedade em vias de midiatização o domínio da técnica pertence a todos. Com isso, os meios perdem sua centralidade e o paradigma da comunicação abandona de vez a especialização, expandindo-se a todos os sujeitos e instituições.

Perdendo a centralidade, os meios perdem seu poder de controle sobre as estruturas da sociedade. A midiatização, então, redinamiza a organização social. Para Jahn (2014, p.72), "vivemos a passagem de sociedades midiáticas para a midiatização da sociedade em que instituições, mídias e sujeitos se afetam mutuamente, de forma não-linear, com multiplicação de tecnomediações setoriais". Essas transformações nas sociabilidades colocadas pelo autor significam que, na sociedade em vias de midiatização, além da disponibilidade da técnica, há uma afetação sobre todas as práticas e atores sociais. O modelo emissor-receptor, baseado na linearidade da emissão, entra em crise, cedendo espaço para a nova figura do receptor-produtivo (ou receptor-ativo), expandindo o acesso da produção e da emissão para os que não possuíam esse direito na sociedade dos meios. A produção do amador nas redes digitais é o grande exemplo dessa mudança. Segundo Hjarvard (2012, p.74), "o principal serviço das novas mídias é produzir relações sociais entre as pessoas, e os usuários são cada vez mais estimulados a gerar conteúdo por si próprios".

Ao falar da produção, emissão e recepção amadora, voltamos ao aspecto da especialização. Na sociedade em midiatização, as especializações e as disciplinas perdem força e por isso podemos dizer que há a transição de uma sociedade dos meios baseada em estruturas para uma sociedade em midiatização baseada nos processos. Processos sócio-técnicodiscursivos reconfigurados em uma nova ambiência que afeta as interações entre todos os sujeitos e instituições. Os espaços fronteiriços entre os campos sociais, geridos pelo campo 
midiático na sociedade dos meios, agora estão verdadeiramente misturados em uma ambiência circulatória nessa sociedade em midiatização.

Gomes (2011) entende essa nova ambiência como mais ampla em comparação ao panorama anterior (meios vistos apenas como dispositivos técnicos). Para o autor, a transição é lenta e gradual, centrada em uma dimensão qualitativa.

O resultado é o compartilhamento de vivências entre as pessoas de todas as gerações. O processo comunicacional possibilita o avanço progressivo da sociedade em níveis cada vez mais complexos. [...] Hoje, com o advento da tecnologia digital, essas interrelações se complexificaram e ampliaram, criando uma nova ambiência (GOMES, 2011, p.6).

Ainda na obra de Gomes (2011) observamos a virtualidade digital como premissa básica da transição. O processo de comunicação é potencializado pela evolução dos meios eletrônicos. A nova ambiência é resultado do desenvolvimento tecnológico. O virtual e o digital trouxeram, segundo o autor, um novo modo de ser no mundo.

\section{Sobre a midiatização...}

Após refletirmos sobre as lógicas de transição da sociedade dos meios para a sociedade em midiatização, passamos a examinar as construções teóricas que envolvem o conceito. Pretendemos atentar para duas problematizações relevantes no contexto da temática. Primeiramente, a midiatização como processo interacional de referência. Em seguida, a questão da circulação.

A nova ambiência, surgida a partir de uma série de mudanças sociotécnicas, fez com que os processos de interação midiatizada passassem a influenciar e absorver os demais. $\mathrm{Ou}$ seja, tudo passa a se ajustar à lógica da mídia. Hjarvard (2012, p.64) está muito próximo dessa ideia ao afirmar que "por midiatização da sociedade, entendemos o processo pelo qual a sociedade, em um grau cada vez maior, está submetida a ou torna-se dependente da mídia e de sua lógica". Processo interacional de referência significa, então, que a midiatização está se tornando a organizadora da sociedade e, consequentemente, responsável pela construção da realidade social.

A realidade social é construída a partir dos processos interacionais hegemônicos. Braga (2006, p.2) defende a "mediatização como processo interacional em marcha acelerada para se tornar o processo de referência", ao fazer alusão à passagem da escrita para a midiatização como o processo interacional de referência. Tal transição, ainda que não estabelecida, encontra-se em um estágio avançado. Aqui voltamos a refletir sobre a midiatização como fenômeno 
incompleto. Afinal, a passagem da escrita para a midiatização como processo interacional de referência tem previsão para se completar? Braga (2006) defende que, se nem mesmo a escrita completou sua jornada como processo interacional de referência, provavelmente a midiatização também não irá. Essa incompletude, como denomina o autor, é resultado do funcionamento social, que é imprevisível. As incompletudes da midiatização são lacunas que devem ser inventadas socialmente. Tratam-se, portanto, de processos tentativos, de experimentação. $\mathrm{Ou}$ seja, sem fim.

\begin{abstract}
A expressão incompletude, na minha visada, significa apenas que é possível perceber com clareza grandes espaços vazios na processualidade, práticas sociais tateantes, conhecimento teórico insuficientemente formulado e - particularmente - uma grande inexperiência sociocultural no uso de tais processos. [...] A mediatização não pode ser considerada estabelecida no mesmo nível em que a cultura escrita foi referência como processo interacional (e ainda é, parcialmente) (BRAGA, 2006, p.17).
\end{abstract}

A interação midiatizada busca maior abrangência e duração, trazendo mais elementos e participantes. Reobjetivação, redeterminação, repercussão, redirecionamento, são características da circulação de reações diferidas e difusas. Se na cultura escrita e na sociedade dos meios havia um foco na emissão, hoje temos uma ênfase no polo receptor, que aproxima as realidades e faz com que a circulação acelerada supere a especialização. Ao expor os campos sociais uns aos outros, a midiatização muda o foco do tratamento da expressão para a recepção.

Falamos em receptor-ativo e na mudança do foco da emissão para a recepção na nova ambiência da sociedade em midiatização. Estamos trazendo para o texto, mesmo que de maneira indireta, o conceito de circulação. Assim como a estávamos trabalhando aqui, nos estudos da comunicação a circulação também foi por muito tempo tratada como algo já historicamente naturalizado. Na sociedade dos meios, circulação se limitava ao intervalo entre emissão e recepção.

Na sociedade em midiatização, o conceito de circulação remete à ambiência. Uma paisagem circulatória é percebida. Fluxos e circuitos enquadram a comunicação no movimento, saindo da visão instrumental/material dos meios, como comentamos anteriormente.

O novo modo de problematizar o conceito de circulação nos faz refletir novamente sobre a insuficiência das teorias clássicas da comunicação. Fausto Neto (2010) explica que a transmissionalidade da sociedade dos meios norteou por décadas o paradigma da comunicação. Emissão, transmissão, transferência, entrega e transporte são exemplos de termos utilizados para a demonstração física do "percurso" realizado pela mensagem ao se deslocar do emissor 
para o receptor. O sucesso dessa transmissão dependia do mediador e por isso a centralidade dada aos meios e a sua técnica.

"Na sociedade em vias de midiatização, o receptor é re-situado em outros papeis na própria arquitetura comunicacional emergente" (FAUSTO NETO, 2010, p.6). Considera-se que o polo receptor faz muito mais do que apenas absorver os estímulos enviados pelo emissor. $\mathrm{O}$ paradigma da linearidade é colocado em questão. Com isso, automaticamente, o princípio da causalidade dos efeitos da mensagem também cai. O receptor é, dessa forma, tratado na mesmas condições que o emissor. Ele desvia ao se apropriar. Ele também produz. Para Fausto Neto (2010, p.9), “a linearidade dá lugar a heterogeneidade. Dissolve-se no ato da enunciação a existência de uma noção de equilíbrio, especialmente vínculos possíveis de simetricidade".

A circulação, agora fenômeno possível de ser localizado e descrito, passa a ser a responsável pela atividade da comunicação. $\mathrm{O}$ emissor perde o poder de controle pelo fato de o receptor não estar mais estático, à espera do estímulo. Fausto Neto (2010) ainda explica que não podemos considerar que não há mais lugar para a recepção. Mesmo com a amplitude do acesso não significa produção automática. A produção/emissão está aberta a qualquer um, mas isso não quer dizer que todos estão produzindo a todo o momento. A complexidade das relações entre produção e recepção, sintetizada no conceito de circulação, possibilita que o ator social esteja ora na posição de produtor, ora na posição de receptor. E ora na posição de coprodutor, por que não?

Trata-se da complexificação do processo de comunicação, e não de sua desobjetivação. Disso não pode resultar a supressão dos lugares de produção e da recepção de discursos, mas sua subordinação a uma nova configuração de regimes de discursividades nos quais o trabalho comunicativo está preso (FAUSTO NETO, 2010, p.8).

Ao problematizar a circulação, Braga (2012) encontra na prática social os circuitos para retratar a realidade. A circulação ainda é abstrata, enquanto o circuito é mais concreto para se observar os fatos comunicacionais da sociedade, ou seja, o empírico. A intenção do autor é visualizar como a circulação afeta as interações entre os campos sociais. "Cada setor ou processo da sociedade participa de circuitos múltiplos" (BRAGA, 2012, p.44). Como comentamos anteriormente, os campos sociais estavam acostumados a interagir a partir de suas próprias lógicas, em negociações fronteiriças geridas pelo campo dos media. Para Braga, na sociedade em midiatização, onde a técnica foi absorvida por todos nessa ambiência circulatória, os circuitos provocam um verdadeiro atravessamento dos campos sociais. 


\begin{abstract}
Ao experimentarem práticas mediáticas, ao se inscreverem, para seus objetivos interacionais próprios, em circuitos midiatizados, ao darem sentidos específicos ao que recebem e transformam e repõem em circulação - os campos sociais agem sobre os processos, inventam, redirecionam ou participam da estabilização de procedimentos de midiatização. Essa processualidade interacional repercute sobre o próprio perfil do campo (BRAGA, 2012, p.45).
\end{abstract}

Assim como Gomes (2011) defende que a evolução dos meios eletrônicos serviu de base para a transição da sociedade dos meios para a midiatização, Fausto Neto (2010) afirma que as novas tecnologias, sobretudo a Internet, são referências diretas da mudança para uma ambiência circulatória, pois a complexificação tecnológica faz exposição do trabalho da circulação.

\title{
Um problema de sistema
}

Após buscarmos uma sintética compreensão do fenômeno da midiatização e da passagem da sociedade dos meios para a sociedade em vias de midiatização, voltemos ao conceito visto na introdução do texto para incluirmos nosso objeto na análise que nos propusemos a fazer.

Espaços que se caracterizam pela resistência e fechamento. Interações desenvolvidas sob um regime extremamente formal, envolto de grande influência da sua simbólica, baseados nas hierarquias e nas disciplinas. Essas são as instituições totais de Goffman. Esse é o Exército Brasileiro, o qual vamos trazer para a esfera da midiatização. Como esse tipo de instituição se comporta na transição da sociedade dos meios para a sociedade em vias de midiatização?

O primeiro passo é reconhecer a instituição (total) Exército Brasileiro como um campo social. Partindo das definições de Rodrigues (2000) para as características de um campo social, encontramos no Exército a capacidade de impor regras a serem respeitadas acerca de um domínio de experiência. Dotado de funções discursivas e pragmáticas, de simbólica formal, de sanções físicas e morais, o Exército pode ser perfeitamente analisado como um campo social afetado por essa nova ambiência da midiatização.

Simbólica formal, disciplina rígida e hierarquia descendente talvez sejam as características de instituição total que mais se encaixam no âmbito do Exército e que melhor o aproximam de um campo social ajustado para interagir segundo a lógica da sociedade dos meios. Isso porque tais características remetem aos mecanismos lineares de causa e efeito que tanto sustentaram o paradigma comunicacional que vigorou antes da transição. A pura transmissionalidade é facilmente verificada empiricamente ao observamos as instruções militares e a relação superior-subordinado. A hierarquia está acima do convencimento. A disciplina ratifica as crenças. A simbólica formal leva ao cumprimento dos ideais. Há espaço 
para algo mais do que o "sim, Senhor"? O militar seria o exemplo do receptor passivo (na posição de sentido) aguardando a mensagem do emissor (superior hierárquico)? Bom, estamos falando das interações dentro do quartel, é claro. Mas, ao levarmos essa reflexão a um escalão superior, como o das negociações entre campos sociais, observamos a característica-chave da instituição total de Goffman, que melhor explica a ligação entre o Exército Brasileiro e a sociedade dos meios.

\footnotetext{
Quando resenhamos as diferentes instituições de nossa sociedade ocidental, verificamos que algumas são muito mais fechadas do que outras. Seu "fechamento" ou seu caráter total é simbolizado pela barreira à relação social com o mundo externo e por proibições à saída que muitas vezes estão incluídas no esquema físico - por exemplo, portas fechadas, paredes altas, arame farpado, fossos, água, floresta ou pântanos. A tais estabelecimentos dou o nome de instituições totais, e desejo explorar suas características gerais (GOFFMAN, 2001, p. 16).
}

Barreiras à relação social. A clausura limítrofe dos quartéis e o formalismo do indivíduo de farda estão tão enraizados na Força que são elevados ao nível de relacionamento com os demais campos sociais. Por isso, o Exército é comparado aqui como instituição total. A autonomização do campo social Exército foi baseada na imposição de suas regras. O respeito às disciplinas e estruturas, característico da sociedade dos meios, possibilitou o reconhecimento público e a legitimação da instituição Exército Brasileiro.

É claro que a Força não deixou de estar dependente do campo dos media, assim como todos os demais campos sociais, quando esse se autonomizou. Como comentamos acima, o Exército permitiu a sua "gerência" por parte dos meios, ao se submeter a sua técnica, extremamente alinhado ao paradigma funcional linear. Mas permitiu menos do que os demais, e quando cedeu, manteve a imposição de suas lógicas. Por isso, o aproximamos de uma instituição total, por ser mais fechado que as demais.

Mas até mesmo nas instituições totais ocorrem desvios. Será que o soldado (o receptor) é passivo, estático? O pelotão (a massa) é totalmente maleável? A intenção (a mensagem) do comando (o emissor) vai mesmo gerar o efeito esperado na tropa? Como vimos anteriormente, a incerteza dos efeitos passa a assombrar o modelo clássico transmissional de comunicação. As possíveis apropriações da esfera da recepção nos fazem reconhecer que, até mesmo nas instituições totais, vão ocorrer desvios. As novas teorias da comunicação e a transição para a sociedade em vias de midiatização colocam em xeque a ausência de conflitos. "Antes de ver as organizações como ambiente de regularidades, pretende-se pensá-las como 'realidades comunicacionais', envoltas em problemáticas associadas às noções de conflitos, incertezas, desregulagens..." (FAUSTO NETO, 2008, p.43). Nem toda a rigidez na disciplina vai esconder 
os desvios da apropriação. Os espaços mais fechados também passam a ser afetados por essa nova ambiência e, consequentemente, cai o pressuposto de que não há crise nas hierarquias.

Chegamos a um momento que não é de regulação. A midiatização substitui as estruturas por processos de interação. Os modos de negociação dos campos sociais passam a entrar em crise e as buscas por legitimação vão se tornando mais complexas. Todas as instituições estão à frente de novos desafios para introduzir suas lógicas na ambiência circulatória. Ou seja, todos têm que reaprender a "chamar a atenção".

No caso específico de uma instituição total, a situação é mais delicada. Retomando Braga (2012), ao atravessar os campos sociais por circuitos, a midiatização organiza a sociedade a partir do transdisciplinar. Os domínios de experiência misturados, afetando uns aos outros, fazem com que os campos sociais - sempre em busca de legitimação - reconheçam a obrigatoriedade de buscar novas formas de negociação com os demais. Ocorre que, para o Exército Brasileiro (para uma instituição total), exposição midiática intensa e aceitação de outras lógicas rompem com as barreiras (muitas vezes físicas) que resguardam a clausura do sistema. Tais barreiras podem ser comparadas às fronteiras que dividiam os campos sociais. $\mathrm{O}$ Exército não está acostumado a escutar, a anunciar, muito menos a aceitar ou compreender outras hierarquias. Mas até que ponto ele vai se sustentar como campo social autônomo sem estar inserido e adaptado na ambiência da sociedade em vias de midiatização?

Já defendemos que as estruturas foram substituídas pelos processos. Ao tratar da crise da disciplinarização, que emerge das novas relações de poder criadas na "sociedade em rede", Castells (2009) afirma que as disciplinas também foram substituídas, no caso, pelas redes. O autor, ao pensar o mundo a partir da nova configuração de uma sociedade informacional, coloca sob tensão o conceito de poder, sugerindo novas formas de poder não tão determinísticas, que estão presentes na sociedade atual, ligadas às redes (estruturas comunicativas). A obra de Castells conversa de maneira muito próxima com o conceito de circulação. Mas esse não é o foco do nosso texto. O que queremos aproveitar das redes de Castells é o estudo que é feito sobre movimentos sociais a partir da autocomunicação. Para o autor, a reprogramação das redes (contra o poder programado) possibilita a mudança social. Como exemplo empírico, ele traz o movimento dos ecologistas. Castells descreve a trajetória dos cientistas que, visando a tematização pública da questão ecológica, buscaram por décadas o apoio da técnica dos media até reconhecerem a necessidade de se tornarem ativistas políticos para manter a atenção da sociedade. Da sua maneira, Castells explica a trajetória da apropriação das técnicas midiáticas, somada a uma visão transdisciplinar de interação com outros campos sociais, em prol da legitimação da causa ecológica. 


\begin{abstract}
De manera que cuando los científicos empezaron a preocuparse seriamente por sus hallazgos sobre el calientamento global, trataron de dirigirse a los políticos o al público directamente, por ejemplo escribiendo libros de divulgación. [...] Los científicos que decidieron provocar al público tuvieron que aprender algunos trucos [...] Así, aunque los científicos fueron responsables del descubrimiento del calientamiento global e hicieron el primer intento de alertar al público sobre la gravedad del asunto, tuvieron que convertirse en activistas y tomar parte en los movimientos ecologistas para llegar a todo el mundo (CASTELLS, 2009, p. 418).
\end{abstract}

A obra de Castells nos permite enxergar como a circulação está atravessando os campos sociais. O campo científico, autonomizado primeiramente a partir do domínio a experiência de seus especialistas, necessitou entregar-se ao campo dos media para tematizar a questão ecológica no espaço público fronteiriço da sociedade dos meios. Na transição para a sociedade em midiatização, com a interação transdisciplinar dentro de uma ambiência circulatória em que o campo social se abre a outras lógicas, o cientista apropria-se das técnicas (não só midiáticas, mas de outros campos) e passa a negociar diretamente com a sociedade, sem a mediação do campo midiático. Agora, novamente nos perguntamos: o Exército seria capaz de adotar tal postura?

A nova ambiência não permite o isolamento total a mais ninguém. A midiatização é uma espécie de poder transversal, que afeta a todos, sem exceção. Para os sistemas que se adaptam com facilidade, a transição transcorre normalmente. Agora, para o Exército Brasileiro, um sistema reativo por essência, a complexidade da transição é maior. Para uma instituição total, à primeira vista, a midiatização é um fenômeno de pura ruptura. Encarar a perspectiva de continuidade para a adaptação regular não parece ser uma opção convidativa. Mas as discursividades começam a se fragilizar perante as questões atravessadas pela circulação midiática. Vejamos o caso da homossexualidade dentro da Força. Como manter a preservação discursiva das lógicas da caserna perante esse assunto? O senso comum tem o conhecimento de que os militares nunca aprovaram homoafetividade dentro da Força. Ocorre que hoje não podem mais afirmar isso abertamente para a sociedade. Por outro lado, também não pode haver produção de novas discursividades, pois isso seria um risco para os valores seculares da instituição. Este tema nos faz notar como o campo social Exército parece estar isolado. Mas isolado dentro de uma ambiência circulatória? Será possível a resistência contra as afetações que provém da midiatização?

Fausto Neto (2010), ao trabalhar a circulação como o resultado da diferença entre os processos de produção e recepção, nos ajuda a entender por que é tão complicada a preservação da lógica discursiva da Força, ao negociar "da sua maneira” com os sujeitos e instituições. 
De um lado, gramáticas fortemente estruturadas, no seio de instituições, de discursos midiáticos. E de outro, a emergência de multiplicidades de gramáticas que se fundam e se orientam em diversidades de lógicas oriundas do mundo dos atores e dos indivíduos, articulando-os a um trabalho. No lugar da homogeneização de sentidos, a diversidade e heterogeneidade de estratégias (FAUSTO NETO, 2010, p.10).

Segundo Braga (2012, p.45), “todos os campos sociais, na sociedade em midiatização, parecem estar mais atrelados a necessidades de interação 'externa', mesmo à custa de não poder impor suas lógicas para dizer suas coisas". Novamente, reforçamos a ideia de que há uma pressão pelo transdisciplinar na ambiência da midiatização. O poder e a vigilância do midiático impõem a abertura de todos os sistemas, inclusive os mais fechados - as instituições totais. A pergunta não é se a midiatização deve ser reconhecida ou não. Trata-se de como responder à problemática da midiatização.

"Os campos sociais passam a interagir com ambientes externos a suas lógicas canônicas, produzindo assim emergentes processos e outras lógicas, próprios da midiatização" (XAVIER, 2014, p.46). As interações entre as diferentes lógicas dos diversos campos sociais, dentro de uma ambiência em que o processo humano de comunicação é potencializado pelos avanços tecnológicos, forma o que Gomes (2011) chama de caldo cultural da midiatização. O compartilhamento de vivências, a circulação de conteúdos, possibilita um avanço da humanidade para um nível mais complexo.

Partindo dessa visão, parece difícil que alguma instituição não queira estar mergulhada nesse "caldo cultural". Mas para aqueles que são fechados e reativos por essência, o receio da perda de seus valores dogmáticos parece ser maior do que o interesse pela mudança, ainda que tal mudança possa trazer benefícios.

Ainda assim, como afirmamos anteriormente, nem mesmo as instituições totais são resumidas apenas a regularidades. Nada garante a ausência de conflitos. Com isso queremos dizer que já existem algumas formações no interior da caserna com vista à adaptação a essa transição para uma sociedade em midiatização. Ou seja, o Exército, da sua maneira, está participando do processo, sofrendo afetações da nova ambiência. A área de comunicação social hoje é reconhecida e vem se desenvolvendo dentro da Força. Operações abertas para coberturas jornalísticas, disponibilidade das fontes, iniciativas de relações púbicas para promoção de interações com profissionais e estudantes de outras áreas, são exemplos de atividades que, sob a influência do midiático, o Exército faz e que não estava acostumado a fazer. Os próprios quartéis estão bem mais abertos às comunidades do que há anos atrás. O poder transversal da midiatização está afetando até mesmo a instituição total, ainda que de uma maneira peculiar. 
Carlon (2013) estuda como os meios massivos convivem nessa nova ambiência, em conjunto aos novos meios. $\mathrm{O}$ autor defende que "la comunicación masiva sigue también em los nuevos médios" (CARLON, 2013, p.231), pelo fato de que os novos meios não mataram o massivo, pois tudo convive na chamada convergência. O Youtube é um dos exemplos citados, pois mesmo criado com a intenção do broadcast yourself (do conteúdo gerado pelo usuário), ele acaba também fortalecendo os grandes emissores institucionais, oriundos do massivo. Entendemos com isso que aquelas clássicas instituições da sociedade dos meios, emissoras por essência e fortemente ligadas ao paradigma funcional linear, também podem se apropriar das novas técnicas do midiático. Ou seja, todos têm condições de adaptação a essa sociedade em vias de midiatização. O Exército também pode acomodar-se em uma posição confortável nessa ambiência circulatória? Por que não? Mas talvez a instituição tenha que deixar de ser tão "total”.

\section{Conclusão}

A transição da sociedade dos meios para a sociedade em vias de midiatização coloca os meios em uma matriz societária. O paradigma da comunicação evolui e não é mais privilégio do campo dos media. A comunicação não é um fenômeno linear, ou seja, não há ajuste de sentidos. Há uma nova dinâmica de simetria. A ênfase agora está na esfera da recepção, dentro de uma ambiência circulatória fortemente influenciada pelas novas tecnologias.

A midiatização está se estabilizando como processo interacional de referência. Tal processo está em desenvolvimento pelo fato de que a midiatização é, por essência, um conceito não fechado, em construção. A própria comunicação é tentativa e por isso sempre apontará incompletudes, que terão de ser inventadas socialmente.

Os campos sociais, anteriormente fragmentados por espaços fronteiriços, estão misturados e atravessados pela midiatização. As experiências não estão mais fundadas em estruturas e as disciplinas não controlam mais a arquitetura social. Todas as instituições são afetadas nessa ambiência, inclusive as mais fechadas, denominadas instituições totais por Goffman, conceito que aproximamos do Exército Brasileiro.

Como uma instituição baseada na hierarquia, na disciplina e na barreira social, responde à problemática da midiatização? À primeira vista, resistência, receio pela perda da autonomia que já foi conquistada, mesmo envolta das mesmas necessidades crescentes de legitimação que pressionam os demais campos sociais. Mas examinando a fundo algumas pistas deixadas pelas interações, percebem-se algumas formações embrionárias no interior do reduto que dão indícios a uma tentativa de adaptação. 


\begin{abstract}
Não estamos sugerindo que os campos sociais se diluirão em favor de uma espécie de "comunicação direta" da sociedade através de redes difusas. Mas afirmamos que as mudanças decorrentes de processos de interação "em midiatização" modificam (e modificarão crescentemente) o perfil, os sentidos e os modos de ação dos campos sociais; que outros campos se desenvolvem; e sobretudo que os modos de interação entre os campos sociais e entre cada um destes e a sociedade ao largo continuarão a se modificar. (BRAGA, 2012, p.46)
\end{abstract}

Para concluirmos sobre reação ou adaptação, há uma necessidade de construção teórica e empírica muito maior. O que não nos deixa dúvida é a afetação geral que provém dessa nova ambiência. O campo social não vai se perder na midiatização, mas com certeza ele é ressignificado. A midiatização é um poder transversal superior a qualquer campo social. Quando o processo se torna referência, nada escapa a ele.

\title{
Referências
}

BRAGA, José Luiz. Circuitos versus campos sociais. In: MATOS, Maria Ângela; JANOTTI JUNIOR, Jeder; JACKS, Nilda Aparecida. Mediação e midiatização: Livro Compós 2012. Salvador/Brasília: UFBA, COMPÓS, 2012. P. 31-52.

BRAGA, José Luiz. Mediatização como processo interacional de referência. Apresentado no grupo de trabalho Comunicação e Sociabilidade, do XV Encontro da Compós, na Unesp, Bauru, São Paulo, em julho de 2006.

CARLON, Mario. Ataque a los poderes, médios "convergentes" y giro antropocêntrico: el nuevo escenario com base em internet. In: VERÓN, Eliseo; FAUSTO NETO, Antonio; HEBERLÊ, Antonio Luiz O. Pentálogo III: Internet: Viagens nos espaço e no tempo. Pelotas: Editora Cópias Santa Cruz, 2013. P. 207-228.

CASTELLS, Manuel. Comunicación y poder. Madrid: Alianza Editorial, 2010.

FAUTO NETO, Antonio. A Circulação além das bordas. Mediatización, sociedad y sentido: Diálogos Brasil y Argentina. Rosário: UNR, 2010. P. 2-17.

FAUSTO NETO, Antonio. Comunicação das organizações: da vigilância aos pontos de fuga. In: OLIVEIRA, Ivone de Lourdes; SOARES, Ana Thereza Nogueira. Interfaces e tendências da comunicação no contexto das organizações. São Caetano do Sul: Difusão Editora, 2008.

GOMES, Pedro Gilberto. Da sociedade dos mídias à sociedade em midiatização. Paper. Ppgcc, Unisinos. São Leopoldo, 2013.

HJARVARD, Stig. Midiatização: teorizando a mídia como agente de mudança social e cultural. Matrizes, São Paulo, ano 5, n², p.53-91, já/jun 2012.

JAHN, Carlos Alberto. Indeterminações comunicacionais geradoras de indefinição ética: um estudo de casos múltiplos de dispositivos interacionais, circuitos comunicacionais e lógicas tentativas. São Leopoldo, 2014.

RODRIGUES, Adriano. Experiência. Modernidade e campo dos media. In: SANTANA, Raimundo Nonato Monteiro de (Org). Reflexões sobre o mundo contemporâneo. Teresina: Revan, 2000. P. 169-15.

XAVIER, Monalisa Pontes. A consulta transformada: experimentações de dispositivos interacionais "psi” na sociedade em midiatização. São Leopoldo, 2014. 